Psychometric Properties of Internet Gaming Motives Scale Gaming Motives as Predictor of Internet Gaming Disorder

\author{
Jia Yuin Fam, Rumaya Juhari, Mohd Najmi Daud \& Zainal Madon
}

To Link this Article: http://dx.doi.org/10.6007/IJARBSS/v11-i12/11797

DOI:10.6007/IJARBSS/v11-i12/11797

Received: 20 October 2021, Revised: 22 November 2021, Accepted: 07 December 2021

Published Online: 25 December 2021

In-Text Citation: (Fam et al., 2021)

To Cite this Article: Fam, J. Y., Juhari, R., Daud, M. N., \& Madon, Z. (2021). Psychometric Properties of Internet Gaming Motives Scale Gaming Motives as Predictor of Internet Gaming Disorder. International Journal of Academic Research in Business and Social Sciences, 11(12), 541-551.

Copyright: (c) 2021 The Author(s)

Published by Human Resource Management Academic Research Society (www.hrmars.com)

This article is published under the Creative Commons Attribution (CC BY 4.0) license. Anyone may reproduce, distribute, translate and create derivative works of this article (for both commercial and non0-commercial purposes), subject to full attribution to the original publication and authors. The full terms of this license may be seen

at: http://creativecommons.org/licences/by/4.0/legalcode

Vol. 11, No. 12, 2021, Pg. 541 - 551

http://hrmars.com/index.php/pages/detail/IJARBSS

JOURNAL HOMEPAGE

Full Terms \& Conditions of access and use can be found at http://hrmars.com/index.php/pages/detail/publication-ethics 


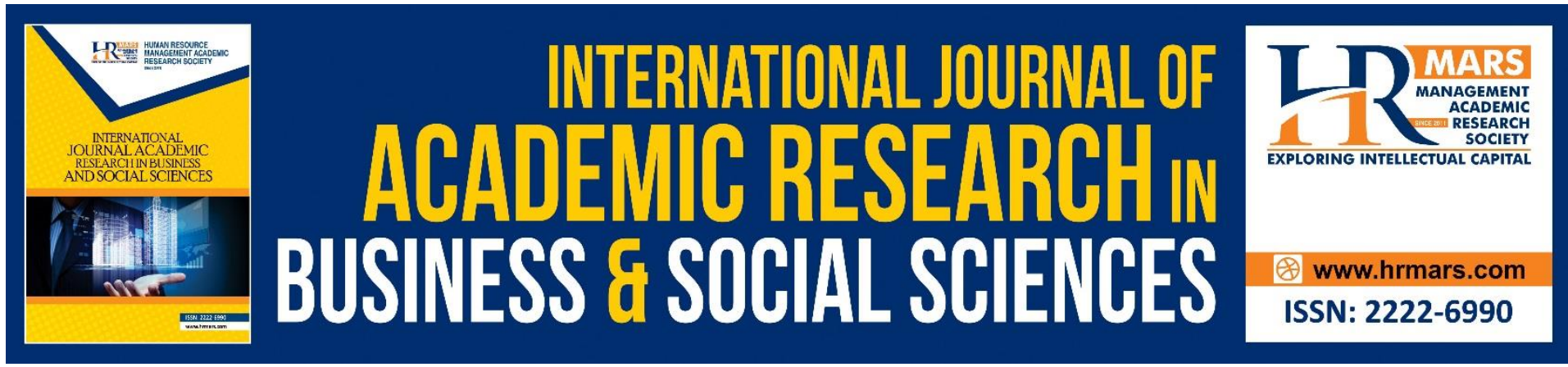

\title{
Psychometric Properties of Internet Gaming Motives Scale Gaming Motives as Predictor of Internet Gaming Disorder
}

\author{
Jia Yuin Fam ${ }^{1,2}$, Rumaya Juhari', Mohd Najmi Daud ${ }^{1}$ \& Zainal \\ Madon ${ }^{1}$ \\ ${ }^{1}$ Faculty of Human Ecology, Universiti Putra Malaysia, ${ }^{2}$ Department of Psychology, HELP \\ University Subang 2 \\ Email: jiayuin.f@help.edu.my, rumaya@upm.edu.my
}

\begin{abstract}
Studies of the gaming motives had primarily focused on online gamers. Although there are studies that applied the Online Gaming Motivation Scale in the offline settings, more psychometric evidence in the offline setting is needed to warrant for meaning comparison. The aim of the current study is to evaluate the psychometric properties of the Online Gaming Motivation Scale and to examine the predictive role of gaming motives to internet gaming disorder. A total of 614 adolescent gamers of online and offline games participated in the current study. The confirmatory factor analysis supports the three-factor structure of the Online Gaming Motivation Scale (namely social, immersion, and achievement motives). Pearson correlation, average variance extracted, composite reliability, and reliability analysis support the excellent psychometric properties of the Online Gaming Motivation Scale. Hierarchical multiple regression found gaming motives as significant predictors of internet gaming disorder among adolescent gamers of online and offline games.
\end{abstract}

Keywords: Online Gaming Motivation Scale, Motive, Internet Gaming Disorder, Psychometric, Confirmatory Factor Analysis

The inclusion of internet gaming disorder as a condition that requires further study in the fifth edition of Diagnostic and Statistical Manual of Mental Disorders (DSM-5; American Psychiatric Association, 2013) had encouraged much research into the topic. On one hand, studies had examined the potential comorbidities of internet gaming disorder, such as depression (Liu et al., 2018), generalized anxiety disorder (Wang et al., 2017), and autism spectrum disorder (Murray et al., 2021). On the other hand, studies had explored potential predictors of internet gaming disorder, which include family factors (Schneider, King, \& Delfabbro, 2017), biopsychosocial factors (Sugaya, Shirasaka, Takahashi, \& Kanda, 2019), and individual differences (Gervasi et al., 2017).

Of the various studies been conducted, there are increasing studies that look into the motivational component of internet gaming disorder. A number of quantitative and 
qualitative studies had been conducted to identify and classify the gaming motives. Bartle (2004) proposed four types of gaming motives, namely achievers, explorers, socializers, and killers. The motivational model was attempted by Yee (2006). However, Yee (2006) identified ten components of gaming motives that can be classified into three higher-order factors, namely social (socializing, relationship, teamwork), immersion (discovery, role-playing, customization, escapism), and achievement (advancement, mechanics, competition). In another study, Demetrovics et al (2011) identified seven types of gaming motives, which are escape, coping, fantasy, skill development, recreation, competition, and social.

Instead of looking at internet gaming disorder as compulsive behaviour, it is plausible that individuals engage in internet gaming disorder with a specific motive, whereby they are expecting a positive outcome from the gaming activities ((Wu et al., 2016). For this reason, studies had explored the relationships between the gaming motives and internet gaming disorder (Edy et al., 2018; Hsu et al., 2009; Laconi et al., 2017), whereby studies generally suggested that there are some motivations that drive the individuals to engage in internet gaming disorder. Kardefelt-Winther (2014) proposed a theory of compensatory internet use where individuals are motivated to go online to fulfil unmet needs. For instance, adolescents with dysfunctional peer relationships might be motivated to play internet games for social motives. Although the adolescents might be able to fulfil the unmet needs in short term, they will become increasingly dependent on internet gaming and lost the ability to make offline friends in the longer term.

Although the majority of past studies support the relationship between gaming motives and internet gaming disorder, it is noteworthy that many of the past studies placed the main focus on the online gamers (Billieux et al., 2011; Fuster et al., 2013; Király et al., 2015), with scarce research been conducted among offline gamers. For example, Kuss et al (2012) found gaming motives (escapism and mechanics) as significant predictors of excessive gaming among MMORPG players. In fact, the DSM-5 mentioned that IGD "most often involves specific Internet games, but it could involve non-Internet computerized games as well, although these have been less researched" (American Psychiatric Association, 2013, p. 796). In examining the measurement invariance of the Problematic Online Gaming Questionnaire, Smohai et al (2017) found the online and offline gamers to respond differently to social-related motives (overuse, interpersonal conflicts, and social isolation), but respond similarly to other motives (obsession, preoccupation, and withdrawal symptoms). Yet, studies had found social motives as a weaker predictor for internet gaming disorder than other gaming motives (for review, see King et al., 2019). This signals the need to further examine the predictive role of gaming motives to internet gaming disorder in offline settings. It is plausible that the motivational model could be expanded to the offline setting as well.

In search of the current literature, two measures of gaming motives are frequently been applied in the current research settings, which are the Online Gaming Motivation Scale (Yee et al., 2012) and the Motives for Online Gaming Questionnaire (Demetrovics et al., 2011). Although both measures were designed to examine gaming motives among online game players, it is notable that many studies had utilized the Online Gaming Motivation Scale in diverse settings, which include Pokémon GO (Kaczmarek et al., 2017), recreational video games (Comello, Francis, Marshall, \& Puglia, 2016), and female general gamers (LopezFernandez et al., 2019). To encourage more research into this area, there is a need to examine 
the psychometric properties of the Online Gaming Motivation Scale in the general gamer's population.

Considering the aforementioned facts, the aim of the current study is two-fold. First, it is the aim of the current study to examine the psychometric properties of the Online Gaming Motivation Scale, involving online and offline gamers. Second, the current study aimed to examine the predictive role of gaming motives to internet gaming disorder. In particular, the current study placed the main focus on adolescent online and offline gamers. The selection of this sample is primarily due to the high prevalence rate of internet gaming disorder had repeatedly been raised in past studies (Fam, 2018).

\section{Method}

\section{Participants and Procedures}

A total of 614 adolescent online and offline gamers participated in the current study. The adolescent gamers were aged between 12 and 18 (Mean $=15.36, S D=1.275$ ), with 285 males (46.4\%) and 329 females (53.6\%). Of these adolescent gamers, $70.8 \%$ played both online and offline games, $20.0 \%$ played online games only, and $9.1 \%$ played offline games only.

Data of the current study were collected between October and November 2019. The adolescent gamers were recruited from 12 secondary schools in Selangor, Malaysia. All students identified from the randomly selected classes were invited to complete a self-report questionnaire anonymously during the regular school day. There are a few inclusion criteria for the current study, whereby the adolescent gamers must be: (a) Malaysian; (b) enrolled in Malaysian public secondary school during the data collection period, (c) aged between 12 and 20 years old, and $(d)$ online or offline gamer.

\section{Materials}

\section{Demographic}

Participants were required to report their age, gender, game mode (online or offline), and time spent gaming per day (in hour).

\section{Online Gaming Motivation Scale}

The Online Gaming Motivation Scale (Yee et al., 2012) contains 12 items that identify motives to play games, which include social $(\alpha=.77)$, immersion $(\alpha=.75)$, and achievement motives $(\alpha=.74)$. The items are rated on a 5-point Likert scale, ranging from 1 (not important at all) to 5 (extremely important). Although the scale was originally designed to examine motives to play online games, the scale had been utilized in different game genres (Kaczmarek et al., 2017).

\section{Problem Videogame Playing Scale}

The Problem Videogame Playing (PVP) Scale (Tejeiro \& Bersabé, 2002) has nine items that examine problems associated with the addictive use of video games (e.g., When I can't use the video games, I get restless or irritable). The items are designed as dichotomous yes/no responses. A total score is obtained by summing the nine items, with a higher total score indicates a more severe internet gaming disorder. The PVP scale demonstrated good internal consistency $(\alpha=.81)$ in the current study. 


\section{Statistical Procedure}

The present study applied various data analysis methods through the Statistical Package for Social Science version 23 (SPSS) and Amos 23. First, descriptive analysis was performed to examine the characteristics of the Online Gaming Motivation Scale at the item level. Second, confirmatory factor analysis (CFA) was performed to evaluate the factor structure of the Online Gaming Motivation Scale. The model was evaluated with a set of fit indices as recommended by El-Den, Schneider, Mirzaei, and Carter (2020). Third, a series of psychometric analyses were performed, namely Pearson correlation analysis, average variance extracted (AVE), composite reliability (CR), and reliability analysis. Lastly, hierarchical multiple regression was performed to examine the predictive role of gaming motives on internet gaming disorder.

\section{Result}

\section{Descriptive Analysis}

Descriptive analysis was performed to examine the characteristics of the Online Gaming Motivation Scale at the item level (Table 1). Values of skewness and kurtosis are within the acceptable range of \pm 2 , supporting the assumption of normality.

\section{Factorial Validity}

CFA was performed to examine the original three-factor structure of the Online Gaming Motivation Scale, with each item were permitted to load on the intended factor as proposed by Yee et al. (2012). The results showed a good fit to the data $\left(\chi^{2} / d f=3.613, \mathrm{CFI}=.966, \mathrm{TLI}=\right.$ .956 , RMSEA $=.065$, SRMR $=.036$ ). All items were well-loaded to the three motives with $p<$ .001 , namely social (standardized factor loadings range between .663 and .796), immersion (standardized factor loadings range between .699 and .767), and achievement motives (standardized factor loadings range between .727 and .846).

\section{Internal Structure}

Pearson correlation analysis was performed to examine the relationships between the three motives (Table 3 ). Social motive was positively correlate with immersion motive, $r(612)=.612$, $p<.001$, and achievement motive, $r(612)=.680, p<.001$. Additionally, significant positive relationship was found between immersion motive and achievement motive, $r(612)=.666, p$ $<.001$. The significant relationships between the gaming motives support the internal structure of the Online Gaming Motivation Scale.

\section{Convergent Validity}

AVE and CR were computed to evaluate the convergent validity of the Online Gaming Motivation Scale (Table 3). Overall, the AVE (range between .543 and .633) and CR (range between .826 and.873) for the three gaming motives are above the threshold recommended by El-Den et al. (2020). Therefore, the convergent validity of the Online Gaming Motivation Scale was supported.

\section{Internal Consistency}

Reliability analysis with Cronbach's $\alpha$ was performed to examine the internal consistency of the Online Gaming Motivation Scale (Table 3). The overall scale demonstrated excellent internal consistency (Cronbach's $\alpha=.918$ ). More specifically, the social, immersion, and 
achievement motives also demonstrated good internal consistency (Cronbach's as range between .823 and .871).

\section{Gaming Motives as Predictors of Internet Gaming Disorder}

Hierarchical multiple regression was performed to examine the predictive role of gaming motives to internet gaming disorder (Table 4). In Step 1, demographic variables (age, gender, and time spent gaming) were entered into the regression against internet gaming disorder. The three demographic variables explain around $26.5 \%$ of the variance in internet gaming disorder $\left(R^{2}=.265\right)$.

In Step 2, the three gaming motives from the Online Gaming Motivation Scale were simultaneously entered into the regression. All variables explain close to $36.2 \%$ of the variance in internet gaming disorder $\left(R^{2}=.362\right)$. The three gaming motives positively predict internet gaming disorder ( $\beta$ s range between .098 and .166), which explain an additional $9.7 \%$ of the variance. More precisely, adolescent gamers that are older, male, spent more time gaming, and play games for social, immersion, or achievement are more likely to demonstrate higher level of internet gaming disorder.

\section{Discussion}

The current study aimed to examine the psychometric properties of the Online Gaming Motivation Scale in a sample of 614 adolescent online and offline gamers. The psychometric analyses support the factorial validity, internal structure, and internal consistency of the Online Gaming Motivation Scale. Additionally, hierarchical regression revealed gaming motives as significant predictors of internet gaming disorder.

Results of the CFA support the three-factor structure for the Online Gaming Motivation Scale as proposed by Yee et al (2012). The identified factors are social, immersion, and achievement motives. Traditionally, studies suggested that massively multiplayer online role-playing games (MMORPGs) are more addictive than offline games, primarily due to MMORPGs will (a) serves as an environment for socializing (social motive); (b) offer a persistent virtual world (immersion motive); and (c) contains an advancement system which allows players to continuously develop (achievement motive; Billieux et al., 2015). However, due to technological advancement, more recent offline games will share similar structural characteristics to MMORPGs. It is not surprising that adolescent gamers will play offline games with the same set of gaming motives as online games.

Aside from that, the Pearson correlation revealed significant positive relationships between the three gaming motives. The results indicate that the three factors are significantly correlated but tap into different domains of gaming motives, evidencing the internal structure of the Online Gaming Motivation Scale. The AVE and CR support the convergent validity of the Online Gaming Motivation Scale. Reliability analysis also supports the internal consistency of the Online Gaming Motivation Scale (Cronbach's as range between .82 and .87), with comparably higher Cronbach's alpha values than the original study (Cronbach's as range between .74 and .77; Yee et al., 2012).

The result of hierarchical multiple regression revealed gaming motives as significant predictors of internet gaming disorder, as expected and previously reported in the online 
gaming settings (Billieux et al., 2013; Király et al., 2015; Kuss et al., 2012). The current findings further demonstrate the potential expansion of the motivational model into the offline gaming settings (with $20 \%$ of the current sample played online games only). More precisely, adolescent gamers who play games to (a) communicate and socialize with other gamers or in-game characters; (b) explore and immerse into the virtual world; and (c) compete and accomplish game success, are at higher risk to engage in internet gaming disorder. At this point, some might question the social component in offline games. However, the more recent game designs had created the possibility for "electronic friends" (Colwell \& Kato, 2003), whereby the player-game interactions might provide socializing opportunities for the offline gamers. Hence, it is reasonable to expand the motivational model to offline settings.

Nonetheless, there are some limitations that should be addressed. First, the current study was designed as a cross-sectional study, interpretation of the direction of prediction is largely based on theoretical reasoning and past findings. Longitudinal studies and experimental studies are highly welcomed to further examine the causal relationship. Second, the majority of the participants played both online and offline games (70.8\%). An additional one-way ANOVA revealed a significant difference in internet gaming disorder between the three game modes, $F(2,611)=22.94, p<.001$. Bonferroni post hoc analysis revealed significant differences between all pairwise comparisons, with adolescents that played both online and offline games reported highest level internet gaming disorder (Mean $=4.11, \mathrm{SD}=2.581$ ), followed by online gamers (Mean $=3.32, \mathrm{SD}=2.526$ ) and offline gamers (Mean $=1.79, \mathrm{SD}=$ 2.239). In light of this consideration, it is plausible that adolescents that played offline games only are under-represent in the current study. Future research is encouraged to recruit more offline gamers for more meaningful comparison. Third, it is noteworthy that the RMSEA value for the three-factor structure of the Online Gaming Motivation Scale is slightly higher than the threshold proposed by El-Den et al. (2020). Further evaluation of the three-factor structure should strengthen the psychometric properties of the Online Gaming Motivation Scale.

In conclusion, the Online Gaming Motivation Scale demonstrated good psychometric properties in the current study, whereby it remains a valid and reliable measure of gaming motives in the offline setting. The predicting role of gaming motives to internet gaming disorder should encourage more studies to further evaluate the motivational model of internet gaming disorder.

\section{Reference}

American Psychiatric Association. (2013). Diagnostic and Statistical Manual of Mental Disorders (5th ed.). doi: 10.1176/appi.books.9780890425596

Bartle, R. A. (2004). Designing virtual worlds. New Riders. https://books.google.com.my/books?id=z3VP7MYKqalC

Billieux, J., Chanal, J., Khazaal, Y., Rochat, L., Gay, P., Zullino, D., \& Van der Linden, M. (2011). Psychological predictors of problematic involvement in massively multiplayer online role-playing games: Illustration in a sample of male cybercafé players. Psychopathology, 44(3), 165-171. doi: 10.1159/000322525

Billieux, J., Deleuze, J., Griffiths, M. D., \& Kuss, D. J. (2015). Internet gaming addiction: The case of massively multiplayer online roleplaying games. In N. El-Guebaly, G. Carrà, M. 
Galanter, \& A. M. Baldacchino (Eds.), Textbook of addiction treatment: International perspectives (pp. 1515-1525). doi: 10.1007/978-88-470-5322-9_105

Billieux, J., Van der Linden, M., Achab, S., Khazaal, Y., Paraskevopoulos, L., Zullino, D., \& Thorens, G. (2013). Why do you play World of Warcraft? An in-depth exploration of self-reported motivations to play online and in-game behaviours in the virtual world of Azeroth. Computers in Human Behavior, 29(1), 103-109. doi:

10.1016/j.chb.2012.07.021

Colwell, J., \& Kato, M. (2003). Investigation of the relationship between social isolation, selfesteem, aggression and computer game play in Japanese adolescents. Asian Journal of Social Psychology, 6(2), 149-158. doi: 10.1111/1467-839X.t01-1-00017

Comello, M. L. G., Francis, D. B., Marshall, L. H., \& Puglia, D. R. (2016). Cancer survivors who play recreational computer games: Motivations for playing and associations with beneficial psychological outcomes. Games for Health Journal, 5(4), 286-292. doi: 10.1089/g4h.2016.0003

Demetrovics, Z., Urbán, R., Nagygyörgy, K., Farkas, J., Zilahy, D., Mervó, B., Reindl, A., Ágoston, C., Kertész, A., \& Harmath, E. (2011). Why do you play? The development of the motives for online gaming questionnaire (MOGQ). Behavior Research Methods, 43(3), 814-825. doi: 10.3758/s13428-011-0091-y

Edy, D. F., Bellani, E., \& Arifin, M. (2018). Motive on playing online game as predictor of adolescence's problematic online gaming use in Makassar. 8th International Conference of Asian Association of Indigenous and Cultural Psychology, Indonesia.

El-Den, S., Schneider, C., Mirzaei, A., \& Carter, S. (2020). How to measure a latent construct: Psychometric principles for the development and validation of measurement instruments. International Journal of Pharmacy Practice, 28, 326-336. doi: 10.1111/ijpp.12600

Fam, J. Y. (2018). Prevalence of internet gaming disorder in adolescents: A meta-analysis across three decades. Scandinavian Journal of Psychology, 59(5), 524-531. doi: 10.1111/sjop.12459

Fuster, H., Carbonell, X., Chamarro, A., \& Oberst, U. (2013). Interaction with the game and motivation among players of massively multiplayer online role-playing games. The Spanish Journal of Psychology, 16. doi: 10.1017/sjp.2013.54

Gervasi, A. M., La Marca, L., Costanzo, A., Pace, U., Guglielmucci, F., \& Schimmenti, A. (2017). Personality and internet gaming disorder: A systematic review of recent literature. Current Addiction Reports, 4(3), 293-307. doi: 10.1007/s40429-017-0159-6

Hsu, S. H., Wen, M. H., \& Wu, M. C. (2009). Exploring user experiences as predictors of MMORPG addiction. Computers \& Education, 53(3), 990-999. doi: 10.1016/j.compedu.2009.05.016

Kaczmarek, L. D., Misiak, M., Behnke, M., Dziekan, M., \& Guzik, P. (2017). The Pikachu effect: Social and health gaming motivations lead to greater benefits of Pokémon GO use. Computers in Human Behavior, 75, 356-363. doi: 10.1016/j.chb.2017.05.031

Kardefelt-Winther, D. (2014). A conceptual and methodological critique of internet addiction research: Towards a model of compensatory internet use. Computers in Human Behavior, 31, 351-354. doi: 10.1016/j.chb.2013.10.059

King, D. L., Delfabbro, P. H., Perales, J. C., Deleuze, J., Király, O., Krossbakken, E., \& Billieux, J. (2019). Maladaptive player-game relationships in problematic gaming and gaming disorder: A systematic review. Clinical Psychology Review, 73. doi: 10.1016/j.cpr.2019.101777 
Király, O., Urbán, R., Griffiths, M. D., Ágoston, C., Nagygyörgy, K., Kökönyei, G., \& Demetrovics, Z. (2015). The mediating effect of gaming motivation between psychiatric symptoms and problematic online gaming: An online survey. Journal of Medical Internet Research, 17(4). doi: 10.2196/jmir.3515

Kuss, D. J., Louws, J., \& Wiers, R. W. (2012). Online gaming addiction? Motives predict addictive play behavior in massively multiplayer online role-playing games. Cyberpsychology, Behavior, and Social Networking, 15(9), 480-485. doi: 10.1089/cyber.2012.0034

Laconi, S., Pirès, S., \& Chabrol, H. (2017). Internet gaming disorder, motives, game genres and psychopathology. Computers in Human Behavior, 75, 652-659. doi: 10.1016/j.chb.2017.06.012

Liu, L., Yao, Y. W., Li, C. S. R., Zhang, J. T., Xia, C. C., Lan, J., Ma, S. S., Zhou, N., \& Fang, X. Y. (2018). The comorbidity between internet gaming disorder and depression: Interrelationship and neural mechanisms. Frontiers in Psychiatry, 9. doi: 10.3389/fpsyt.2018.00154

Lopez-Fernandez, O., Williams, A. J., \& Kuss, D. J. (2019). Measuring female gaming: Gamer profile, predictors, prevalence, and characteristics from psychological and gender perspectives. Frontiers in Psychology, 10. doi: 10.3389/fpsyg.2019.00898

Murray, A., Koronczai, B., Király, O., Griffiths, M. D., Mannion, A., Leader, G., \& Demetrovics, Z. (2021). Autism, problematic internet use and gaming disorder: A systematic review. Review Journal of Autism and Developmental Disorders. doi: 10.1007/s40489-02100243-0

Schneider, L. A., King, D. L., \& Delfabbro, P. H. (2017). Family factors in adolescent problematic Internet gaming: A systematic review. Journal of Behavioral Addictions, 6(3), 321-333. doi: 10.1556/2006.6.2017.035

Smohai, M., Urbán, R., Griffiths, M. D., Király, O., Mirnics, Z., Vargha, A., \& Demetrovics, Z. (2017). Online and offline video game use in adolescents: Measurement invariance and problem severity. The American Journal of drug and Alcohol Abuse, 43(1), 111116. doi: 10.1080/00952990.2016.1240798

Sugaya, N., Shirasaka, T., Takahashi, K., \& Kanda, H. (2019). Bio-psychosocial factors of children and adolescents with internet gaming disorder: A systematic review. BioPsychoSocial Medicine, 13(3). doi: 10.1186/s13030-019-0144-5

Tejeiro, R. A., \& Bersabé, R. M. (2002). Measuring problem video game playing in adolescents. Addiction, 97(12), 1601-1606. doi: 10.1046/j.1360-0443.2002.00218.x

Wang, C. Y., Wu, Y. C., Su, C. H., Lin, P. C., Ko, C. H., \& Yen, J. Y. (2017). Association between Internet gaming disorder and generalized anxiety disorder. Journal of Behavioral Addictions, 6(4), 564-571. doi: 10.1556/2006.6.2017.088

Wu, J. Y. W., Ko, H. C., Wong, T. Y., Wu, L. A., \& Oei, T. P. (2016). Positive outcome expectancy mediates the relationship between peer influence and Internet gaming addiction among adolescents in Taiwan. Cyberpsychology, Behavior, and Social Networking, 19(1), 49-55. doi: 10.1089/cyber.2015.0345

Yee, N. (2006). The demographics, motivations, and derived experiences of users of massively multi-user online graphical environments. Presence: Teleoperators and Virtual Environments, 15(3), 309-329. doi: 10.1162/pres.15.3.309 
Table 1

Item Characteristics of the Online Gaming Motivation Scale

\begin{tabular}{lcccc}
\hline Item & Mean & SD & Skewness & Kurtosis \\
\hline Item 1 & 3.08 & 1.431 & -0.106 & -1.279 \\
Item 2 & 2.97 & 1.316 & -0.004 & -1.063 \\
Item 3 & 3.35 & 1.271 & -0.366 & -0.842 \\
Item 4 & 3.72 & 1.231 & -0.694 & -0.497 \\
Item 5 & 3.39 & 1.238 & -0.296 & -0.844 \\
Item 6 & 2.87 & 1.284 & 0.096 & -0.964 \\
Item 7 & 3.10 & 1.242 & -0.075 & -0.864 \\
Item 8 & 3.10 & 1.369 & -0.071 & -1.190 \\
Item 9 & 3.53 & 1.286 & -0.483 & -0.818 \\
Item 10 & 3.34 & 1.354 & -0.330 & -1.085 \\
Item 11 & 3.44 & 1.250 & -0.416 & -0.777 \\
Item 12 & 3.63 & 1.332 & -0.603 & -0.830 \\
\hline
\end{tabular}

Table 2

Confirmatory Factor Analysis for the Online Gaming Motivation Scale

Item $\begin{gathered}\text { Standardized Factor } \\ \text { Loading }\end{gathered}$

Social

1. Chatting with other players.

$.774[.727, .817]$

2. Being part of a guild.

$.796[.748, .836]$

3. Grouping with other players.

$.791[.739, .837]$

4. Keeping in touch with your friends.

$.663[.597, .724]$

Immersion

5. Learning about stories and lore of the world.

$.767[.721, .808]$

6. Feeling immersed in the world.

$.699[.631, .758]$

7. Exploring the world just for the sake of exploring it.

$.756[.697, .803]$

8. Creating a background story and history for your character. $\quad .723[.665, .770]$

Achievement

9. Becoming powerful.

$.787[.738, .828]$

10. Acquiring rare items.

$.818[.772, .855]$

11. Optimizing your character as much as possible.

$.846[.808, .876]$

12. Competing with other players.

$.727[.672, .775]$

Table 3

Psychometric Properties for the Online Gaming Motivation Scale

\begin{tabular}{|c|c|c|c|c|c|}
\hline Motive & Social & Immersion & AVE & CR & $\begin{array}{c}\text { Cronbach's } \\
\alpha\end{array}$ \\
\hline Online Gaming Motivation Scale & & & .583 & .944 & .918 \\
\hline Social & 1 & & .575 & .843 & .841 \\
\hline Immersion & $.612 * * *$ & 1 & .543 & .826 & .823 \\
\hline Achievement & $.680 * * *$ & $.666 * * *$ & .633 & .873 & .871 \\
\hline
\end{tabular}

Note. $\mathrm{AVE}=$ average variance extracted; $\mathrm{CR}=$ composite reliability

$* * * p<.001$ 
INTERNATIONAL JOURNAL OF ACADEMIC RESEARCH IN BUSINESS AND SOCIAL SCIENCES Vol. 11, No. 12, 2021, E-ISSN: 2222-6990 @ 2021 HRMARS

Table 4

Regression Coefficients of Age, Gender, Time Spent Gaming, and Gaming Motives on Internet Gaming Disorder

\begin{tabular}{lcccccc}
\hline Variable & \multicolumn{3}{c}{ Step 1 } & \multicolumn{3}{c}{ Step 2 } \\
\cline { 2 - 7 } & $\mathrm{B}$ & $\mathrm{SEB}$ & $\beta$ & $\mathrm{B}$ & $\mathrm{SEB}$ & $\beta$ \\
\hline Age & 0.195 & 0.073 & $.095^{* *}$ & 0.246 & 0.068 & $.119^{* * *}$ \\
Gender ${ }^{\mathrm{a}}$ & 1.323 & 0.198 & $-.251^{* * *}$ & -0.697 & 0.198 & $-.132^{* * *}$ \\
Time spent gaming & 0.292 & 0.033 & $.336^{* * *}$ & 0.236 & 0.031 & $.271^{* * *}$ \\
Social & & & & 0.060 & 0.029 & $.098^{*}$ \\
Immersion & & & & 0.082 & 0.029 & $.129^{* *}$ \\
Achievement & & & & 0.099 & 0.029 & $.166^{* *}$ \\
& & & & & .362 & \\
$\mathrm{R}^{2}$ & & .265 & & & .097 & \\
$\mathrm{R}^{2}$ change & & .265 & & & $57.343^{* * *}$ & \\
$\mathrm{~F}$ & & $73.232^{* * *}$ & & &
\end{tabular}

a Male $=0$, female $=1$

$* p<.05,{ }^{* *} p<.01, * * * p<.001$ 